\title{
The Relationship Between the Mean Platelet Volume and the Development of Spontaneous Ascites Fluid Infection in Patients with Decompensated Cirrhosis
}

\author{
Ebru Sinem Bilgin, ${ }^{1}$ Banu Boyuk, ${ }^{2}$ Osman Maviş, ${ }^{2}$ Rahime Özgür
}

\section{'Department of Internal Medicine, Hopa Goverment Hospital Artvin, Turkey \\ ${ }^{2}$ Department of Internal Medicine Taksim Training and Research Hospital, İstanbul, Turkey \\ Submitted: 03.01.2020 Accepted: 20.03.2020}

Correspondence: Banu Boyuk Taksim Eğitim ve Araştırma Hastanesi, İç Hastalıkları Kliniği, İstanbul, Turkey

E-mail: banuilk@gmail.com

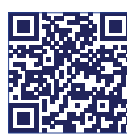

Keywords: Cirrhosis; mean platelet volume; spontaneous ascites infection.

\section{c) (\$)}

This workislicensed underaCreate Conm This workis thensedunder a Creative Commons

\begin{abstract}
Objective: Spontaneous ascitic fluid infection (SAI) is one of the frequent and important complication of decompensated cirrhosis with high mortality. Mean platelet volume (MPV) is a parameter that shows the activity, stimulation and production of platelets. Changes in MPV are important indicators of platelet production, and are also an indicator of the severity of many diseases, such as sepsis, thrombosis, or even respiratory distress syndrome. In our study, we aimed to analyze the relationship between spontaneous ascites infection and mean platelet volume.
\end{abstract}

Methods: 98 cirrhosis patients (42 females, 56 males) with various etiologies were participated to the study. The patients were divided into two groups as SAI positive group including patients with ascitic culture positive and/or ascites polymorphonuclear leukocyte count $(\mathrm{PMNL})>250 \mathrm{~mm}^{3}$ and SAI negative group including patients with no bacterial reproduction in their ascites fluid culture and ascites PMNL count $<250 \mathrm{~mm}^{3}$.

Results: There were 52 patients as 19 females and 33 males, in SAl positive group and 46 patients as 23 females and 23 males, in SAI negative group. In spontaneous ascites infectionpositive group, spontaneous ascites infection mean platelet volume $(p<0.00 \mathrm{I})$ and leukocyte count $(\mathrm{WBC})(p<0.001)$ were detected to be significantly different statistically compared to the negative group. There was no statistically significant difference between the mean platelet volume $(p=0.795)$ and platelet distribution percentage $(p=0.775)$ in SAI positive patients $(p>0.05)$.

Conclusion: Mean platelet volume in patients with spontaneous ascites infection who have developed, decompensated cirrhosis significantly increases. It is possible to use this test which is cheap, non-invasive and fast in the early diagnosis and treatment to follow-up of spontaneous ascites infection.

\section{INTRODUCTION}

Spontaneous ascites infection (SAl) which is one of the most significant complication of decompensated liver cirrhosis, was observed very frequently and causes high mortality. An indication of severe liver failure, spontaneous ascites infection occurs in nearly $10 \%$ to $30 \%$ of cirrhosis patients with ascites. SAl is generally observed in patients with advanced stage liver cirrhosis and may be more rarely observed in fulminant liver failure, chronic alcoholic hepatitis and noncirrhotic liver diseases that cause ascites formation. In cirrhosis patients, bacteria may come into systemic circulation due to insufficiency of the cellular and humoral immune system and may spread to ascites with lengthened bacteremia. A variety of factors like intestinal bacterial permeability, reticuloendothelial system function disorder, low opsonin activity in peritoneal fluid, acute gastrointestinal system (GIS) hemorrhage and low serum complement levels play a role in development of SAI. ${ }^{[1]}$

In cirrhosis patients, death may occur rapidly due to ascites infection. After the first SAI attack, survival rates increase if early diagnosis is made, and with developed diagnostic methods and appropriate empirical treatment methods. ${ }^{[2]}$ If decompensated liver cirrhosis patients with ascites are suspected of spontaneous ascites infection, some tested inflammatory markers may be supportive to begin early prophylaxis before ascites culture results. Inflammation is an important stimulus for platelets. Mean platelet volume 
is a parameter showing the activity, stimulation and productivity of platelets. ${ }^{[3]}$ Changes in mean platelet volume are associated with platelet production and it is a marker of changes in the severity of a variety of diseases. Mean platelet volume is studied as a simple, cheap, rapid and reliable inflammatory marker in many diseases. ${ }^{[4]}$ In our study we aimed to research the correlation of spontaneous ascites infection with mean platelet volume.

\section{MATERIALS AND METHODS}

Our study was retrospectively screened the files and tests of 98 patients with liver cirrhosis diagnosis from 2014 to 2018. Patients without paracentesis performed, with active GIS hemorrhage and with additional systemic infections apart from spontaneous ascites infection was not included in the study. Patients using medications that can affect platelet count and functions and the coagulation system, nonsteroidal anti-inflammatories, aspirin, oral anticoagulants and oral contraceptives were excluded from the study. SAI was defined as proliferation of bacteria in ascites fluid and/or ascites fluid polymorphonuclear leukocyte count above $250 / \mathrm{mL}$, which was surgically treatable with no clear infection source. Patients with secondary peritonitis, acute pancreatitis, peritoneal carcinomatosis or accompanying secondary malignancy was removed from the study. From all patients at least $10 \mathrm{~mL}$ ascites fluid was removed with paracentesis and samples with appropriate seeding in BACTEC culture tubes for aerobic and anaerobic culture were investigated in microbiology laboratory. Cases were divided into two main groups according to whether spontaneous ascites infection developed or not. The first group comprised of 52 patients as 19 females and as 33 males, who developed spontaneous ascites infection. The second group comprised of 46 patients as 23 females and as 23 males, who did not develop spontaneous ascites infection. For SAI diagnosis, ascites culture positivity was not a required criterion. Patients with SIA were divided into three subgroups according to the variables investigated.

I. Monomicrobial nonneutrocytic bacterascites (MNB) group: polymorphonuclear leukocyte (PMNL) count in ascites fluid $<250 / \mathrm{mm}^{3}$ with proliferation of one microorganism in ascites fluid culture $(n=7)$

2. Culture negative neutrocytic ascites (CNNA) group: PMNL count in ascites fluid $>250 / \mathrm{mm}^{3}$, without proliferation in culture $(n=34)$

3. Classic spontaneous bacterial peritonitis (SBP) group: PMNL count in ascites fluid $>250 / \mathrm{mm}^{3}$ and bacterial proliferation identified in ascites fluid culture $(n=I I)$ Patients were examined for age, sex, hemogram, CRP, ESR, PLT, WBC, INR, serum albumin, serum total bilirubin, MPV, PDW, urea, creatinine, $\mathrm{Na}$, ascites albumin-protein, ascites fluid culture and ascites fluid microscopy. The MPV, PDW, Hb, WBC, and PLT values were examined with a Mindray BC-6200 device while CRP, ESR, serum albumin, serum total bilirubin, urea, creatinine and $\mathrm{Na}$ values were examined in the bio- chemistry laboratory with a Beckman Coulter AU 2700 device, and INR was examined with a Diagon Coay XL device. Ascites fluid culture and ascites fluid microscopy were performed in the microbiology laboratory seeded on blood, chocolate and Mac-Conkey agars with gram staining. These were incubated for 24-48 hours and studied with a BACTEC FX device. For each patient, serum-ascites albumin gradient (SAAG) was calculated. Patients had Child-Pugh, MELD and MELD Na scoring performed. Patients were classified according to these scoring methods. The differences in MPV and PDW values between patients developing or not developing $\mathrm{SAI}$ and the association of these parameters with other infective parameters were investigated. Analyses are made for the prognostic correlation between spontaneous ascites infection and mean platelet volume.

\section{Statistical analyze}

Categoric variables are given as frequency and percentage. Continuous variables are given as mean, standard deviation, median, minimum and maximum values. The Kolmogorov Smirnovtest was performed to test the normal distribution of continuous variables. Variables abiding by the assumption of normal distribution had the independent samples $\mathrm{T}$ test used to compare two independent groups. Variables not abiding by the assumption of normal distribution used the Mann Whitney $U$ test for comparison of two independent groups with the Kruskall Wallis $\mathrm{H}$ test used for comparisons of more than two groups.

ROC curve analyses were used for SAI cut-off for mean platelet volume and leukocyte count measurements. $\mathrm{P}<0.05$ was accepted as statistically significant.

Analyses were performed with the NCSS II (Number Cruncher Statistical System, 2017 Statistical Software) Program and MedCalc Statistical Software version 18 (MedCalc Software bvba, Ostend, Belgium; http://www. medcalc.org; 2018).

\section{RESULTS}

Our study includes a total of 98 patients with ascites linked to liver cirrhosis. Of cases, 42 were female (42.86\%) and 56 were male $(57.14 \%)$ with mean age of 67.98 years. There were 52 patients $(53.06 \%)$ with spontaneous ascites infection identified and 46 patients (46.94\%) without infection identified. Patients with spontaneous ascites infection identified were classified according to stages. Of SAl patients, 34 had CNNA (65.38\%), I I had classic SBP (21.15\%) and 7 had MNB (13.46\%). Liver cirrhosis severity was staged with the modified Child-Turcotte-Pugh score. There were no cases with Child-A identified, 37 cases with Child-B (37.76\%), and $6 \mathrm{I}$ cases with Child-C stage (62.24\%). Table I presents the frequency and percentage distributions of the variables. Table 2 gives the descriptive statistics like mean, standard deviation, minimum and maximum values related to the variables. The results of the analysis was detected the mean age as 67.98 years, mean 
Table I. Frequency and percentage distribution of variables

\begin{tabular}{lcc}
\hline & $f$ & $\%$ \\
\hline SAI & & \\
$\quad$ Negative & 46 & 46.94 \\
$\quad \begin{array}{l}\text { Positive } \\
\text { Gender }\end{array}$ & 52 & 53.06 \\
$\quad$ Male & & \\
$\quad$ Female & 56 & 57.14 \\
Child pugh stage & 42 & 42.86 \\
2 & & \\
3 & 37 & 37.76 \\
Assit culture & 61 & 62.24 \\
0 & & \\
I & 83 & 84.69 \\
SAl type & 15 & 15.31 \\
0 & & \\
Classic SBP & 46 & 46.94 \\
CNNA & 11 & 11.22 \\
MNB & 34 & 34.69 \\
\hline
\end{tabular}

Kolmogorov Smirnov test; SBP: spontaneous bacterial peritonitis; CNNA: Culture negative neutrocytic ascites; MNB: Monomicrobial nonneutrocytic bacterascites.

Table 2. Demographic and laboratory characteristics in the patients

\begin{tabular}{lc}
\hline & $\begin{array}{c}\text { (n=98) } \\
\text { Mean } \pm \text { SD }\end{array}$ \\
\hline Age & $67.98 \pm 10.74$ \\
Child Pugh score & $10.08 \pm 1.77$ \\
Meld Na score & $18.96 \pm 7.52$ \\
MELD score & $16.59 \pm 6.77$ \\
Hemoglobin & $10.17 \pm 1.88$ \\
White blood cells & $7522.24 \pm 5327.27$ \\
PLT & $126214.29 \pm 93869.43$ \\
C-reactive protein & $45.32 \pm 43.86$ \\
Mean platelet volume & $9.64 \pm 1.06$ \\
Platelet distribution width & $17.88 \pm 3.31$ \\
Eritrosit sedimentation rate & $36.45 \pm 24.93$ \\
INR & $1.5 \pm 0.44$ \\
Assit albumin & $0.74 \pm 0.67$ \\
Assit protein & $2.02 \pm 1.72$ \\
Serum albumin & $2.54 \pm 0.58$ \\
Serum assit albumin gradient & $1.82 \pm 0.57$ \\
Creatinin & $1.28 \pm 0.88$ \\
Serum sodium & $133.13 \pm 6.13$ \\
Serum total bilirubin & $3.62 \pm 4.19$ \\
\hline
\end{tabular}

Kolmogorov Smirnov test; MELD: Model for end-stage liver disease; PLT: Platelet; INR: International Normalized Ratio.

Child-Pugh score was 10.08, mean MELD Na score was 18.96, mean MELD score was 16.59, mean $\mathrm{Hb}$ level was 10.17, mean WBC level was 7522.24, mean PLT level was I262|4.29, mean CRP level was 45.32, mean MPV level was 9.64, mean PDW level was 17.88, mean ESR level was 36.45, mean INR level was I.5, ascites albumin was 0.74 , mean serum albumin level was 2.54, mean SAAG level was I.82, mean creatinine level was I.28, mean $\mathrm{Na}$ level was I33.13 and mean serum total bilirubin level was 3.62.

Table 3 comparatively investigates some variables according to SAI. There were no statistically significant differences identified for age $(p=0.795)$, Child-Pugh score $(p=0.624)$, MELD Na $(p=0.096)$ and MELD score $(p=0.07 \mathrm{I})$ levels. According to SAI, there were statistically significant differences identified for MPV $(p=0.00 \mathrm{I})$, WBC $(p=0.00 \mathrm{I})$, CRP $(p=0.017)$ and PLT $(p=0.050)$ levels. Mean platelet volume, platelet and leukocyte counts and CRP levels had higher median values in the positive group compared to the negative group. According to SAI, ESR $(p=0.552)$ was not identified to display statistically significant differences $(p>0.05)$.

According to SAl type of those positive for SAI, MPV $(p=0.795)$ and PDW $(p=0.75 \mathrm{I})$ levels were not identified to show statistically significant differences $(p>0.05)$. These levels had similar median values in the SBP, CNNA and MNB groups (Table 4). For ROC analysis, the cut-off value for SAI positivity was $>10$, and for SAI negativity was inversely $<10$. When the cut-off values for SAI positivity is $>6300$, contrarily for SAl negativity it was $<6300$. The mean platelet volume $(A \cup C=0.700, p=0.002)$ and leukocyte count $(A \cup C=0.690, P=0.003)$ variables were each statistically significant parameters for SAI positivity prediction. MPV >10 and WBC $>6300$ are associated with SAI positive status (Fig. I).

\section{DISCUSSION}

Spontaneous ascites infection is one of the most common and significant complication of liver cirrhosis. For SAI diagnosis the gold standard is diagnostic paracentesis which is associated with complications like hemorrhage, visceral perforation, local infection and permanent leak after paracentesis most of the time. As a result, there is a need for simple, rapid, noninvasive and cheap diagnostic tests for early diagnosis of SAl in cirrhosis patients. ${ }^{[5,6]}$ Research had proven that many tests assist in the diagnosis of ascites infection. A few of these include leucocyte esterase reactive strips, $\mathrm{pH}$ test, ascites fluid lactoferrin level, and serum and ascites fluid procalcitonin levels. However, most of these tests are for research purposes and have very high costs. ${ }^{[7]}$

Platelets are known that these play important roles in the initiation and spread of vascular and inflammatory diseases. Mean platelet volume is accepted as an important parameter for determination of platelet activation. Large platelets are more enzymatically and metabolically active compared to small platelets and are known to be associated with inflammation. ${ }^{[8,9]}$ Platelet distribution width is a marker of the variation in platelet volume and is a parameter associated with active platelet secretion. ${ }^{[10]}$ MPV has been shown for use as a systemic inflammatory marker in a variety of inflammatory diseases though the correlation 
Table 3. Demographic and laboratory characteristics according to the presence of spontaneous acid infection

\begin{tabular}{|c|c|c|c|}
\hline & Negative $(n=46)$ & Positive $(n=52)$ & $\mathbf{p}$ \\
\hline & Mean $\pm S D$ & Mean $\pm S D$ & \\
\hline Age & $67.63 \pm 11.24$ & $68.29 \pm 10.37$ & 0.795 \\
\hline Child Pugh score & $10.13 \pm 1.85$ & $|0.04 \pm 1.7|$ & 0.624 \\
\hline Meld Na score & $20.3 \pm 6.98$ & $17.77 \pm 7.84$ & 0.096 \\
\hline MELD score & $17.8 \pm 6.63$ & $15.52 \pm 6.78$ & 0.071 \\
\hline MPV & $9.26 \pm 0.85$ & $9.98 \pm 1.11$ & $0.001 * *$ \\
\hline CRP & $27.25 \pm 4.01$ & $52.85 \pm 7.32$ & $0.017 *$ \\
\hline ESR & $33.67 \pm 20.82$ & $38.9 \pm 28.04$ & 0.552 \\
\hline PLT & III065.22士91364.08 & $1396 \mid 5.38 \pm 94887.37$ & $0.05^{*}$ \\
\hline WBC & $5646.09 \pm 3110.53$ & $9181.92 \pm 6281.47$ & $0.001 * *$ \\
\hline
\end{tabular}

Table 4. Comparison of MPV and PDW levels in SAI positive patients

\begin{tabular}{lcccc}
\hline & Classic SBP $(\mathbf{n}=I I)$ & $\frac{\text { CNNA }(\mathbf{n}=34)}{\text { Mean } \pm \text { SD }}$ & $\frac{\text { MNB }(\mathbf{n}=7)}{\text { Mean } \pm \text { SD }}$ & $\mathbf{p}$ \\
\cline { 2 - 5 } MPV & $9.96 \pm 1.25$ & $9.97 \pm 1.16$ & $10.06 \pm 0.71$ & 0.795 \\
PDW & $17.65 \pm 2.11$ & $17.81 \pm 3.74$ & $18.96 \pm 3.91$ & 0.751 \\
\hline
\end{tabular}

Kruskall Wallis H test; SD: Standard deviation; MPV: Mean platelet volume; PDW: Platelet distribution width.

between platelets in liver cirrhosis and spontaneous ascites infection which has still not been fully clarified. In our research, we investigated the correlation of spontaneous ascites infection with mean platelet volume.

In our study, when the two groups with SAI+ and SAI- in ascites linked to liver cirrhosis are compared, there were no significant differences in the ages and sexes of patients. When patients with spontaneous ascites infection identified are classified according to stage, most SAI+ patients were observed to have CNNA. Liver cirrhosis was staged with the modified Child-Turcotte-Pugh score. While no Child-A case was identified, there were more Child $C$ cases than Child-B cases. According to the study fulfilled by Galvez-Martinez et al. ${ }^{[1]}$ they detected no clear difference in ages between the SAI+ and SAl- groups, but they showed significant elevation for the female sex among all cases. Additionally, as in our study, the highest rate was found for culture negative neutrocytic ascites. Similar to our study, there were more stage $B$ and stage $C$ patients compared to stage $A$ patients. However, there was no significant difference observed between Stage B and Stage C patients.

In our study, variables about severity of liver cirrhosis were comparatively investigated according to SAI. There were no statistically significant differences identified between the two groups for Child-Pugh score, MELD Na and MELD scores. According to the research fulfilled by Galvez-Martinez et al., ${ }^{[1]}$ they found Child-Pugh score was higher in the SAI+ group when the SAI+ and SAI- groups were compared in terms of Child-Pugh staging. We think the reason for this situation in our study is due to the lack of Child-Pugh Stage A patients and all patients comprising stage $B$ and Stage $C$ patients. In our study, comparison of MPV, CRP, ESR, WBC and PLT levels according to spontaneous ascites infection identified significant elevation in MPV, CRP, WBC and PLT counts independent of ChildPugh stages in the SAI+ group, with no significant difference observed for ESR. Significant elevation of MPV, CRP, ESR and PLT between the 2 groups with SAI+ and SAI- is observed via the study of Amal et al. ${ }^{[12]}$

Additionally, they showed that MPV was the inflammatory marker parameter with highest performance with sensitivity of $73 \%$ and specificity of $85.7 \%$. Additionally, another investigation identified a significant fall occurred in MPV values after treatment compared to before antibiotic treatment in SAl+ patients. The study by Elkafoury et al. ${ }^{[13]}$ found that MPV, PLT, WBC, CRP and ESR were significantly higher in SAI+ patients compared to SAI-Patients. Suvak et al.," ${ }^{[14]}$ similar to our study, found CRP, leukocyte count and mean platelet volume significantly increased in patients with spontaneous ascites infection; however, erythrocyte sedimentation rate was not identified to significantly increase in the SAl+ group compared to the SAl- group. They did not include platelet count in their comparison. Additionally, this study found no correlation between MPV levels and Child-Pugh stage of patients, similar to our study. It is observed via the study of Guler et al. ${ }^{[15,16]}$ that CRP especially in SAl+ patients had greater importance for response to antibiotherapy and treatment surveillance rather than for diagnosis of spontaneous as- 

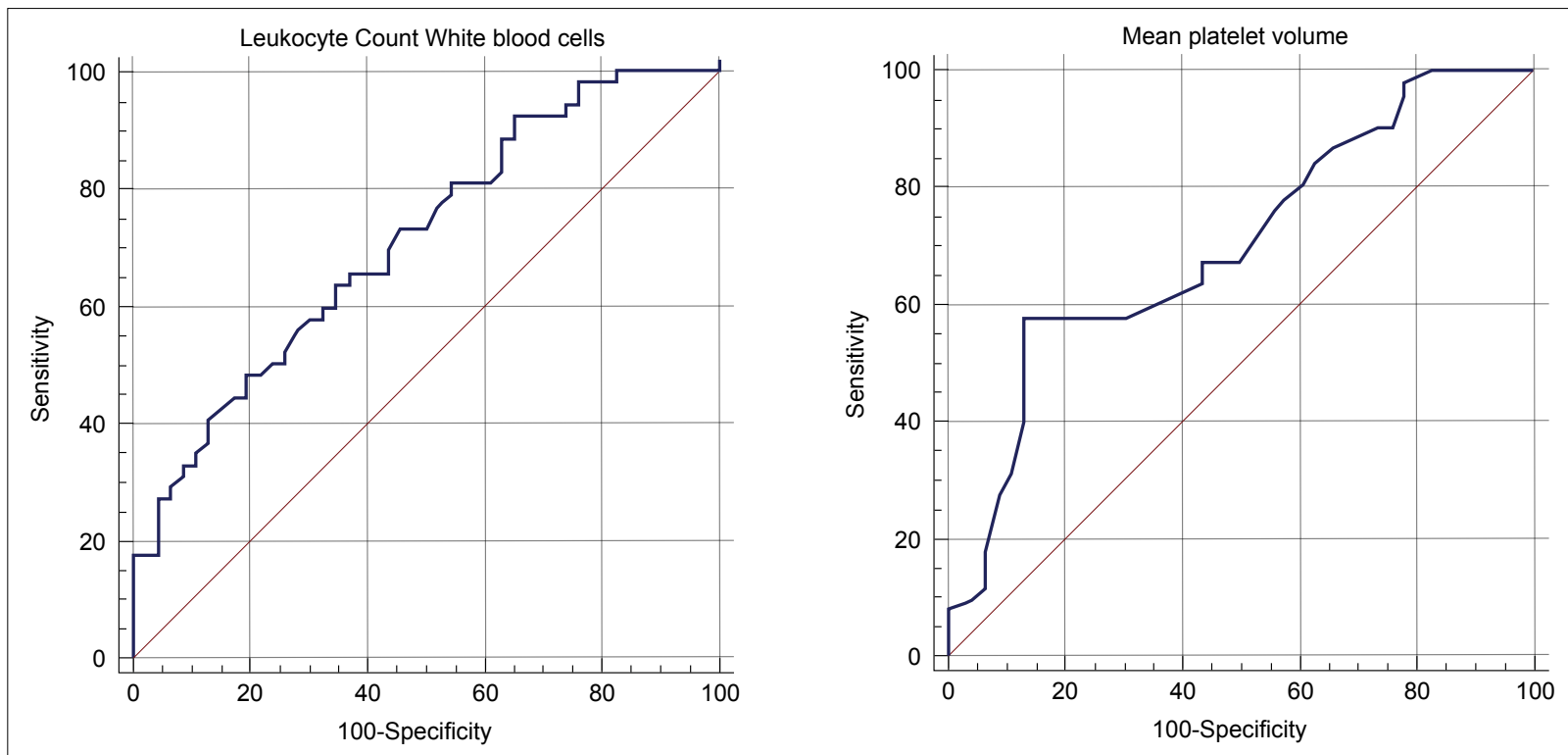

Figure 1. ROC curve analysis for WBC and MPV.

WBC: White blood cells; MPV: Mean platelet volume.

cites infection. Galvez-Martinez et al. ${ }^{[1]}$ investigated the correlation between systemic inflammatory response parameters and mean platelet volume in cirrhotic patients with and without spontaneous ascites infection and found significant elevation of the MPV and WBC counts in the SAI+ group, with no significant difference identified for PLT counts. In the study, they mentioned the difficulty of diagnosing inflammatory response and sepsis for KCS patients with ascites fluid infection due to not showing the classic symptoms and findings of sepsis. ${ }^{[17,18]} A$ few of these that were mentioned included reduced PMNL count linked to hypersplenism, reduced basal heart rate due to hyperdynamic circulation syndrome, hyperventilation syndromes developing due to hepatic encephalopathy and imbalances in body temperature regulation. For these reasons, they discussed the acceptability of mean platelet volume as an important parameter increasing with the systemic inflammatory response.

In our study, we researched the differences in MPV and PDW in both SAI+ and SAl- groups and the correlation of these two variables between spontaneous ascites infection types, which were not previously investigated. Independent of the SAI+ group subgroups of CNNA, MNB and classic SBP, we observed significant increase in MPV compared to the SAl- group. PDW values showed similar features in the SAl- group compared with the SAI+ group independent of the subtypes. In our study, we think that the lack of significant differences in MPV and PDW levels between the 3 groups may be due to numerical inequality between spontaneous ascites infection subtype groups. Studies by Elkafoury et al. ${ }^{[13]}$ compared 3 groups of $\mathrm{SAI}+, \mathrm{SAl}-$ and healthy controls in terms of MPV and PDW and showed the SAI+ patient group had significant elevation of MPV compared to the other two groups, while PDW showed no significant difference. Abdelrazik et al. ${ }^{[19]}$ showed mean platelet volume was significantly elevated in patients with spontaneous ascites infection compared to cirrhosis patients without ascites infection and showed sensitivity rates of $95.9 \%$ and specificity of $91 \%$. Platelet distribution width was not investigated. Mean platelet volume was shown to reflect inflammatory load and disease activity in a variety of diseases like rheumatoid arthritis, celiac disease, acute pancreatitis, acute ischemic stroke, inflammatory bowel diseases, myocardial infarctus, and Alzheimer disease. Though there are contradictory results, there is much evidence associating increased MPV with infection in the literature. ${ }^{[14,20]}$ In cirrhosis patients, polymorphonuclear leukocytes and mean platelet volume are significant variables in the presence of ascites fluid infection identified in many studies, including our study. There is a need for studies performed with larger patient groups for identification of the correlation between MPV and PDW with other infective parameters in spontaneous ascites infection and to bring MPV to the fore as an inflammatory marker. We think to investigate the correlation between SAI subtypes and MPV, especially, will be beneficial in terms of predicting whether there is a correlation between severity of infection and mean platelet volume. In our study, ROC analysis found MPV of 10 and above and WBC of 6300 and above were associated with SAI in the group with spontaneous ascites infection. Suvak et al. $^{[14]}$ identified MPV of 8.45 and above and WBC of 8300 and above were significant for the SAI+ group with ROC analysis. The study by Galvez-Martinez et al. ${ }^{[1]}$ found MPV as $>8.3$ and $\mathrm{WBC}$ as $>8000$ in the $\mathrm{SAl}+$ group. Abdel-Razik et al. ${ }^{[19]}$ identified MPV values of 8.77 and above were associated with infection in SAI+ patients. ${ }^{[17]}$ The publication by Raina et al. ${ }^{[13]}$ found the threshold for MPV in the SAI+ group was $>9.8$.

Due to the retrospective nature of our study, we did not 
have chance to sufficiently monitorthe diagnostic and treatment processes of patients and could not perform sufficient exclusion due to comorbid diseases, which may have caused more limitations compared to prospective studies. Additionally, we think numerical inequality between spontaneous ascites infection subtypes caused the lack of significant increase in mean platelet volume between these groups. New studies with similar rates for each SAI subtype and higher numbers of patients will allow the opportunity to research this topic more clearly.

\section{CONCLUSION}

In decompensated liver cirrhosis patients developing spontaneous ascites infection, mean platelet volumes were significantly increased the modified Child-Turcotte-Puch score, MELD and MELD Na scoring. Additionally, leukocyte count, platelet count and CRP values were increased in association with inflammation in the SAl+ group. Mean platelet volume is a parameter found on the hemogram which is routinely examined in the first stage for each patient. It is possible to use this test as a cheap, noninvasive and rapid method for early diagnosis and treatment to follow-up for spontaneous ascites infection. Studies performed with larger patient groups to investigate this relationship will strengthen the correlation between mean platelet volume and spontaneous ascites infection.

Ethics Committee Approval

Approved by the local ethics committee (GOP Taksim Education and Research Hospital, 2017,12,27/65).

Informed Consent

Retrospective study.

Peer-review

Internally peer-reviewed.

Authorship Contributions

Concept: B.B., E.S.B; Design: B.B., E.S.B; Supervision: O.M,R.O; Data: E.S.B; Analysis: B.B, E.S.B; Literature search: B.B; Writing: E.S.B, B.B; Critical Revision: B.B.

Conflict of Interest

None declared.

\section{REFERENCES}

1. Such J, Runyon BA. Spontaneous bacterial peritonitis. Clin Infect Dis 1998;27:669-74; quiz 675-6. [CrossRef]

2. Atahan Çağatay, Savaş Öztürk. Spontan asit infeksiyonu Klimik Dergisi 2002;15:3-7.

3. Mannaioni PF, Di Bello MG, Masini E. Platelets and inflammation: role of platelet-derived growth factor, adhesion molecules and histamine. Inflamm Res 1997;46:4-18. [CrossRef]
4. Canpolat FE, Yurdakök M, Armangil D, Yiğit S. Mean platelet volume in neonatal respiratory distress syndrome. Pediatr Int 2009;51:314-6.

5. Garcia-Tsao G. Spontaneous bacterial peritonitis. Gastroenterol Clin North Am 1992;21:257-75.

6. Rimola A. Infections in Liver Disease. In: Bircher J, Benhamou JP, McIntyre N, Rizzetto M, Rodes J, editors. Oxford Textbook of Clinical Hepatology. 2nd ed. London, UK: Oxford University Press; 1999. p. 1861-74.

7. Koulaouzidis A, Bhat S, Saeed AA. Spontaneous bacterial peritonitis. World J Gastroenterol 2009;15:1042-9. [CrossRef]

8. Wiest R, Krag A, Gerbes A. Spontaneous bacterial peritonitis: recent guidelines and beyond. Gut 2012;61:297-310. [CrossRef]

9. Gasparyan AY, Sandoo A, Stavropoulos-Kalinoglou A, Kitas GD. Mean platelet volume in patients with rheumatoid arthritis: the effect of anti-TNF- $\alpha$ therapy. Rheumatol Int 2010;30:1125-9. [CrossRef]

10. Dinc B, Oskay A, Dinc SE, Bas B, Tekin S. New parameter in diagnosis of acute appendicitis: platelet distribution width. World J Gastroenterol 2015;21:1821-6. [CrossRef]

11. Gálvez-Martínez M, Servín-Caamaño AI, Pérez-Torres E, SalasGordillo F, Rivera-Gutiérrez X, Higuera-de la Tijera F. Mean platelet volume as a novel predictor of systemic inflammatory response in cirrhotic patients with culture-negative neutrocytic ascites. World J Hepatol 2015;7:1001-6. [CrossRef]

12. Amal A, Mahmoud A, Zeinab H, Zeinab A, Eman A. Mean Platelet Volume is a Promising Diagnostic Marker for Systemic Inflammation in Cirrhotic Patients with Ascitic Fluid Infection. J Mol Biomark Diagn 2017;8:354.

13. Elkafoury RM, Kobtan AA, Attia TE, Abdelhamed HA. Study of platelet indices in cirrhotic patients with spontaneous bacterial peritonitis. Tanta Medical Journal 2018,46:8-15. [CrossRef]

14. Suvak B, Torun S, Yildiz H, Sayilir A, Yesil Y, Tas A, et al. Mean platelet volume is a useful indicator of systemic inflammation in cirrhotic patients with ascitic fluid infection. Ann Hepatol 2013;12:294-300. [CrossRef]

15. Guler K, Vatansever S, Kayacan SM, Salmayenli N, Akkaya V, Erk $\mathrm{O}$, et al. High sensitivity $\mathrm{C}$-reactive protein in spontaneous bacterial peritonitis with nonneutrocytic ascites. Hepatogastroenterology 2009;56:452-5.

16. Kasztelan-Szczerbinska B, Słomka M, Celinski K, Serwacki M, Szczerbinski M, Cichoz-Lach H. Prevalence of spontaneous bacterial peritonitis in asymptomatic inpatients with decompensated liver cirrhosis - a pilot study. Adv Med Sci 2011;56:13-7. [CrossRef]

17. Evans LT, Kim WR, Poterucha JJ, Kamath PS. Spontaneous bacterial peritonitis in asymptomatic outpatients with cirrhotic ascites. Hepatology 2003;37:897-901. [CrossRef]

18. Nousbaum JB, Cadranel JF, Nahon P, Khac EN, Moreau R, Thévenot T, et al. Diagnostic accuracy of the Multistix 8 SG reagent strip in diagnosis of spontaneous bacterial peritonitis. Hepatology 2007;45:1275-81. [CrossRef]

19. Abdel-Razik A, Eldars W, Rizk E. Platelet indices and inflammatory markers as diagnostic predictors for ascitic fluid infection. Eur J Gastroenterol Hepatol 2014;26:1342-7. [CrossRef]

20. Andrews RK, Arthur JF, Gardiner EE. Neutrophil extracellular traps (NETs) and the role of platelets in infection. Thromb Haemost 2014;112:659-65. [CrossRef] 


\section{Dekompanse Karaciğer Sirozlu Hastalarda Assit İnfeksiyonu Gelişiminin Ortalama Trombosit Hacmi ile İlişkisi}

Amaç: Spontan assit enfeksiyonu (SAi) dekompanse karaciğer sirozunun sık, önemli ve yüksek mortaliteye sahip komplikasyonlarından biridir. Ortalama trombosit hacmi (OTH), trombositlerin aktivitesini, uyarılmasını ve üretkenliğini gösteren bir parametredir. OTH'deki değişiklikler trombosit üretiminin önemli bir belirteci olup sepsis, tromboz hatta solunum sıkıntısı sendromu gibi birçok hastalığın şiddetindeki değişikliklerin de bir göstergesidir. Ortalama trombosit hacmi birçok hastalıkta basit, ucuz, hızlı ve güvenilir bir enflamatuvar gösterge olarak çalışıımıştır. Biz çalışmamızda spontan asit enfeksiyonu ile ortalama trombosit hacminin ilişkisini analiz etmeyi amaçladık.

Gereç ve Yöntem: Çalışmaya değişik etyolojilerdeki sirozu olan 98 hasta (42'si kadın, 56'sı erkek) alındı. Hastalar assit mayi kültürü pozitif ve/veya assit polimorfonükleer lökosit sayısı (PMNL) $>250 \mathrm{~mm}^{3}$ olan hastalar SAI+ grup olarak, assit mayi kültüründe üreme olmayan ve assit PMNL sayısı $<250 \mathrm{~mm}^{3}$ olan hastalar SAi- grup olarak iki ana gruba ayrıldı.

Bulgular: SAI+ grupta 19'u kadın 33'ü erkek 52 hasta, SAi- grupta 23'ü kadın 23'ü erkek 46 hasta mevcuttu. Spontan assit enfeksiyonu pozitif olan grupta spontan assit enfeksiyonu negatif gruba göre ortalama trombosit hacmi $(p<0.00$ I), lökosit sayısı $(W B C)(p<0.00 I)$ düzeylerinin istatistiksel olarak anlamlı farklılık gösterdiği tespit edildi. SAI pozitif olanlarda SAi tipine göre ortalama trombosit hacmi $(p=0.795)$ ve trombosit dağılım yüzdesi $(p=0.75 \mathrm{I})$ düzeylerinin istatistiksel olarak anlamlı farklılık göstermediği tespit edildi. $(p>0.05)$.

Sonuç: Spontan assit enfeksiyonu gelişmiş olan dekompanse karaciğer sirozlu hastalarda ortalama trombosit hacmi anlamlı olarak yükselmektedir. Spontan assit enfeksiyonunun erken tanı ve tedavi takibinde ucuz, invaziv olmayan ve hızlı bir şekilde kullanımı mümkün olan bu testin kullanımı mümkündür.

Anahtar Sözcükler: Karaciğer sirozu; ortalama trombosit hacmi; spontan assit enfeksiyonu. 